\title{
EXCHANGE RATE FLUCTUATIONS AND ECONOMIC GROWTH IN NIGERIA (1981 - 2020)
}

\author{
Dr. D. B. Ewubare \\ Department of Economics, Rivers State University, Nkpolu-Oroworukwo, Port \\ Harcourt \\ Ushang Alberta Ushie \\ Department of Economics, Rivers State University, Nkpolu-Oroworukwo, Port \\ Harcourt
}

\begin{abstract}
This study examined the relationship between exchange rate and economic growth in Nigeria between 1981 and 2020. The specific objectives are to determine the effects of exchange rate, inflation and interest rate on gross domestic product (GDP). The data on the variables were obtained from the Central Bank of Nigeria (CBN) Statistical Bulletin and World Development Indicators, and analyzed using descriptive statistics, unit root as well as bounds cointegration tests and ARDL model. The unit root test results showed that the variables are mixed integrated. While inflation is stationary at levels, the other variables in the model were stationary at first difference. The bounds cointegration test showed that long run relationship exists between GDP growth and the underlying explanatory variables. The findings showed that exchange rate and inflation negatively impacted on economic growth. This finding indicates that increase in exchange rate and price level is detrimental to the growth of the Nigerian economy. There is evidence of a significant positive effect of interest rate on GDP growth. This finding explains the reality in Nigeria, where businesses and households tend to borrow even as interest rate increases, but tend to cut corners by reducing the quality of their products and services or pass-on the increased costs of borrowing to consumers by increasing prices. Given the findings, this study recommends amongst others that the federal government through the CBN should ensure that exchange rate policy should is consistent to provide opportunity for a realistic and stable exchange rate capable of driving economic growth in Nigeria.
\end{abstract}

KEYWORDS: exchange rate, inflation rate, interest rate, economic growth

\section{INTRODUCTION}

One of the most extensively discussed topics in Nigeria today is exchange rates and their continual changes. This is unsurprising given its importance as a major

@ECRTD-UK: https://www.eajournals.org/ Journal Level DOI: https://doi.org/10.37745/ijdes.13 
macroeconomic determinant that may help any country achieve its optimum degree of growth and development through optimal productive capacity, particularly in a country like Nigeria that is heavily reliant on imports (Olisadebe, 1991). The exchange rate reflects the ratio at which one currency can be exchanged for another, i.e., the price difference between the two currencies. It is the exchange rate between a foreign currency and the currency of the home country. It also specifies the value of one currency in terms of another. The price of one country's currency represented in terms of another currency is known as the exchange rate. It determines the relative prices of domestic and imported commodities, as well as the degree of the external sector's involvement in international commerce.

The exchange rate of an economy plays a critical role because it has a direct impact on all macroeconomic variables, including domestic price indicators, profitability of traded goods and services, resource allocation, and investment decisions, which explains why monetary authorities and private sectors strive for stability in these variables (Ajakaiye, 2001). It is a crucial macroeconomic variable in the formulation of economic policies in general and economic reform programs in particular, in which these policies aid in the acceleration of macroeconomic goals. In Nigeria, these goals include obtaining and maintaining price stability; achieving and maintaining balance of payment equilibrium; full employment; equitable income distribution; economic growth; and development. In fact, exchange rate swings have become the backbone of all economic operations around the world, making exchange rate management a key driver of many countries' economic strategies (Todaro, 2004).

In the economies of most developed countries, a correct or appropriate exchange rate has been one of the most important factors for economic growth, whereas regular fluctuations or an inappropriate exchange rate have been a major impediment to economic growth in many African countries, including Nigeria.

In a desperate attempt to enhance the standard of living, alleviate poverty, and gain economic and political power, stability, and prestige, Nigeria's monetary authorities have aggressively pursued the goals of internal and external balance since the country's independence in October 1960. They achieved this by administratively altering the local currency's foreign exchange rate in light of the particular and current economic conditions (Osuka \& Osuji, 2008). For at least two reasons, exchange rate changes can have considerable consequences: first, even short-term real exchange rate volatility can impose significant welfare costs (Akpomi \& Kayii, 2021; Jongbo, 2014). Such volatility diminishes international trade, influences investment decisions, and limits

@ECRTD-UK: https://www.eajournals.org/ 
economic opportunities, especially in a constrained environment. Second, in the case of lengthy and sustained exchange rate fluctuations, which can severely distort resource allocation, such welfare costs are amplified. Understanding the key causes of the real exchange rate, as well as distinguishing between short-term and long-term real exchange rate changes in Nigeria, is therefore crucial. Interest rates and exchange rate regimes are still big issues in international finance and in countries that aren't as developed as they used to be. More countries now think that trade liberalization is a must for economic growth (Obansa, Okoroafor, Aluko \& Millicent, 2013).

In Nigeria, the currency rate regime has shifted from controlled to deregulate throughout time. Ewa (2011) acknowledged that the naira's exchange rate was very steady from 1973 to 1979 , when the country was experiencing an oil boom and agricultural products contributed to more than $70 \%$ of the country's gross domestic product (GDP). When the Federal government adopted the Structural Adjustment Policy (SAP) in 1986, the country transitioned from a peg to a flexible exchange rate regime in which the exchange rate is not entirely determined by market forces, but rather the prevailing system is the managed float, in which monetary authorities intervene periodically in the foreign exchange market to achieve some strategic objectives (Mordi, 2006). The inconsistency of policies, combined with the lack of consistency in exchange rate policies, contributed to the instability of the naira rate (Gbosi, 2005).

In 2016, Nigeria witnessed another period in exchange rate after a long wait, the Monetary Policy Committee of the Central Bank of Nigeria has bowed to pressure, thus, directing its management to switch to a flexible exchange rate policy. A flexible exchange rate system is a monetary system that allows the exchange rate to be determined by supply and demand. Every currency area must decide what type of exchange rate arrangement to maintain. Between permanently fixed and completely flexible however, are heterogeneous approaches.

Economic growth connotes a sustained increase in a country's national income (Jhingan, 1997). When the GNP rises eventually, it depicts a growth in the economy. Conversely, economic development refers to the structural and purposeful conversion of all the economic indicators from a low to a high level (Siyan, 2000). Benson and Victor, (2012) and Aliyu, (2011) noted that despite various efforts by the government to maintain a stable exchange rate, the naira has depreciated throughout the 80's to date. In a view of this background, this research study proposes to examine the impact of exchange rate on economic growth in Nigeria over a period of 39 years.

@ECRTD-UK: https://www.eajournals.org/ Journal Level DOI: https://doi.org/10.37745/ijdes.13 
The broad Objective of the study is to investigate the impact of exchange rate fluctuations on the growth of Nigeria's economy. The specific objectives are to:

i. analyze the trends of exchange rate fluctuations in Nigeria over the study period ii. examine the effect of exchange rate on economic growth in Nigeria

iii. determine the effect of inflation rate on economic growth in Nigeria

iv. examine the effect of interest rate on economic growth in Nigeria

v. determine the causality between underlying measures of exchange rate variations and economic growth in Nigeria.

\section{CONCEPTUAL FRAMEWORK}

\section{Economic Growth}

Economic growth refers to an economy's progress as a result of favorable circumstances, such as the progress made by the United Kingdom during the Industrial Revolution. In rich countries, increasing income levels is referred to as "economic growth," while in impoverished countries it is referred to as "economic development" (Maddison, 1982). According to Hicks (1987), the problems of developing countries are related to the development of unused resources even though their uses are wellknown, whereas the problems of developed countries are related to growth, with the majority of their resources already known and developed to a large extent. When comparing one period of time to the next, economic growth is defined as a rise in an economy's capacity to generate products and services. It can be expressed in nominal or real terms, with the latter factoring in inflation. Although alternative metrics are sometimes employed, aggregate economic growth is traditionally quantified in terms of gross national product (GNP) or gross domestic product (GDP). The percentage change in the quantity of goods and services produced from one year to the next is the economic growth rate. It is the same as the actual GDP growth rate.

\section{Exchange Rate}

The monetary model, which was the first to be developed, assumes that the current exchange rate is influenced by current fundamental economic variables such as money supplies and output levels of a country. The model produces the present exchange rate value when the facts are matched with market projections of future exchange rates.

The monetary model is sometimes referred to as the "newspaper model." Journalists frequently use the results of the monetary model when assessing exchange rate changes. When Wall Street experts are asked to justify their exchange-rate forecasts, they almost always use some variation of the monetary model. This model is popular because it is

@ECRTD-UK: https://www.eajournals.org/ 
based on traditional macroeconomic thinking and makes sense to people who don't know much about economics.

The monetary model's logic is straightforward: the exchange rate is decided by the two countries' relative price levels. On average, if goods and services cost twice as much in dollars as they do in a foreign currency, $\$ 2$ will buy one unit of the foreign currency. As a result, the same goods and services will cost the same whether purchased in the United States or abroad (Backus, 1984). But what factors influence the two countries' relative price levels? The monetary model is concerned with money demand and supply. The average level of prices in the United States will tend to grow if the money supply in the United States rises but nothing else changes. Because the foreign country's price level remains constant, more dollars will be required to obtain one unit of foreign currency. As a result, the foreign currency's dollar price will rise; the dollar will depreciate, meaning it will be worth less in terms of the foreign currency. In the monetary model, money supplies aren't the sole basis of economic activity.

\section{Interest Rate}

In Nigeria the Central Bank of Nigeria $(\mathrm{CBN})$ has significant influence on interest rates and setting up of monetary policies. Todaro and Smith (2006) asserted that monetary and fiscal policies play a major direct and indirect role in governmental efforts designed to expand economic activity in times of unemployment and surplus capacity and to contract that activity in times of excess demand and inflation. The level of interest rates and the aggregate supply of money in circulation are the two basic instruments of monetary policies which can either be achieved by controlling the growth of the money supply as argued by monetarist theorist or expanding the supply of money in circulation which in turn leads to excess demand thereby causing the interest rates to decline as argued by the Keynesian economists. These are easily achieved in developed countries where there is highly organized, economically interdependent and efficiently functioning money and credit markets. Despite high inflation rates, real interest rate as at 2001 was over $20 \%$. The persistent high interest rate reduces returns on investment in the real sector and perpetuates trading in financial instruments.

\section{Inflation Rate}

The concept often referred to as inflation has been a major issue in the policy decision in most of the developing countries. Inflation is one of the most frequently used terms in economic discussions, yet the concept is variously misconstrued. There are various schools of thought on inflation, but there is a consensus among economists that inflation is a continuous rise in prices, inflation depicts an economic situation where there is a

@ECRTD-UK: https://www.eajournals.org/ Journal Level DOI: https://doi.org/10.37745/ijdes.13 
general rise in the prices of goods and services continuously, where "too much money is chasing too few goods" Solow-Swan (1956). Jhingan, (2005) defined inflation as a persistent and appreciable rise in the general level of prices. When there is inflation, the currency losses purchasing power. The purchasing power of a given amount of naira in the economy will be smaller over time. In the definition of inflation, two things must be borne in mind. First, is aggregate, which implies that the rise that constitutes inflation must cover the entire basket of goods in the economy as distinct from an isolated rise in the prices of a single commodity or group of commodities. Secondly, the rise in the aggregate level of prices must be continuous for inflation to be said to have occurred. The aggregate price level must show a tendency of a sustained and continuous rise over different time periods.

\section{THEORETICAL LITERATURE}

\section{The Purchasing Power Parity Theory}

According to this theory, the equilibrium rate of exchange is determined by the purchasing power of two inconvertible paper currencies being equal. It means that the internal price levels of two countries influence the rate of exchange between two inconvertible paper currencies. According to the Absolute Version, the rate of exchange equals the ratio of outlay required to buy a particular set of goods at home as compared with what it would buy in a foreign country while according to the Relative version, the equilibrium rate of exchange in the current period (R1) is determined by the equilibrium rate of exchange in the base period (R1) and the ratio of price indices of current and base period in one country to the ratio of price indices of current and base periods in the other country.

\section{The Balance of Payments Theory}

The balance of payments theory of exchange rate maintains that rate of exchange of the currency of one country with the other is determined by the factors which are autonomous of internal price level and money supply. It emphasizes that the rate of exchange is influenced, in a significant way, by the balance of payments position of a country.

\section{EMPIRICAL LITERATURE}

Various studies have been done to examine the relationship between exchange rates and economic growth using various methods and estimation procedures to ascertain the nature of the relationship. Aghin et al (2006) uses annual data for fourteen CEE

@ECRTD-UK: https://www.eajournals.org/ Journal Level DOI: https://doi.org/10.37745/ijdes.13 
countries for the period 2002-2018 to examine the nature and impact of exchange rate volatility on economic growth. The empirical findings using the fixed effects estimation for panel data reveal that the volatility of the exchange rate has a significant negative effect on real economic growth. Odusola and Akinlo (2003) accessed the impact of exchange rate depreciation on output and inflation in Nigeria using the structural version of the reduced form VAR for the period 1970.1-1995.4 and from their findings exchange rate depreciation exercised an expansionary impact on output in the long run but in the short run exchange rate depreciation does not expand output. Adeniran, Yusuf and Adeyemi (2014) in an Empirical Investigation on The Impact of Exchange Rate Fluctuation on Nigerian Economic Growth from 1986 to 2013 using secondary data sourced from Central Bank of Nigeria Statistical Bulletin and Correlation and regression analysis of the ordinary least square (OLS) as methods for data analysis. Their result revealed that exchange rate has positive but not significant impact on economic growth which affirms previous studies that developing countries are relatively better off in the choice of flexible exchange rate regimes. Their result also indicated that interest rate and rate of inflation have negative but not significant impact on economic growth. Alasha (2020) examined the relationship between exchange rate fluctuations and its impact on the Nigerian economic growth using exchange rate, interest rate, inflation rate and trade balance as variables and data sourced from the Central Bank of Nigeria statistical bulletin \& publications from the National Bureau of statistics. Using the classical least regression model and ordinary least square method (OLS) and other techniques such as the Augmented Dickey Fuller test, Cointegration and Granger Causality test to analyze the data. The findings indicated that inflation rates and exchange rates negatively impacts GDP while interest rates have positive impact on GDP.

\section{METHODOLOGY}

\section{Research Design}

Given the nature of this study, an ex post facto research design was adopted for this study. This is based on the fact that the data for this study already exist and cannot be manipulated. This research design also provides the basis for examining the cause-andeffect between the dependent and independent variables.

\section{Data Collection Methods and Sources}

This study utilized time series data from CBN Statistical Bulletin and World Development Indicators.

@ECRTD-UK: https://www.eajournals.org/ Journal Level DOI: https://doi.org/10.37745/ijdes.13 


\section{Model Specification}

The model specification for this study utilized GDP growth as the dependent variable and exchange rate, inflation and interest rate as independent variables. The functional form of the model is as follows:

$\mathrm{GDP}=\mathrm{f}($ EXRT,INFL,ITRS $)$

Where: GDP $=$ Gross domestic product, proxy for economic growth

EXRT $=$ exchange rate

$\mathrm{INFL}=$ inflation rate

ITRS $=$ interest rate

The autoregressive distributed lag (ARDL) model for this study is specified as follows:

$\mathrm{GDP}_{t}=\alpha_{0}+\sum_{i=1}^{P} \alpha_{1 i} \Delta G D P_{t-1}+\sum_{i=1}^{p} \alpha_{2 i} \Delta E X R T_{t-1}+\sum_{i=1}^{p} \alpha_{3 i} \Delta I N F L_{t-1}+\sum_{i=1}^{p} \alpha_{4 i} \Delta I T R S_{t-1}$

$+\beta_{1 i} i G D P_{t-1}+\beta_{2 i} E X R T_{t-1}+\beta_{3 i} I N F L_{t-1}+\beta_{4 i} I T R S_{t-1}+e_{t}$

Where: $\alpha_{0}=$ constant parameter

$\alpha_{1}-\alpha_{4}=$ short run estimates of the regressors

$\beta_{1}-\beta_{5}=$ long run multipliers

$e_{\mathrm{t}}=$ error term

$\Delta=$ first difference operator

$\mathrm{p}=$ maximum lag order

\section{Pre-estimation Tests}

i. Unit Root Test

ii. Bounds Cointegration Test

\section{Method of Data Analysis}

The ARDL method proposed by Pesaran and Shin (1999) was applied in this study to estimate the dynamic long and short relationship between GDP growth and the explanatory variables. The ARDL model allows for easy application and interpretation as it involves a single equation set-up and provides room for assigning different lag to different variables in the model. Furthermore, descriptive statistics was applied in this study for analyzing the distribution of the variables over the study. The estimated model was also subjected to post estimation to evaluate its reliability.

@ECRTD-UK: https://www.eajournals.org/ Journal Level DOI: https://doi.org/10.37745/ijdes.13 


\section{RESULTS AND DISCUSSION}

\section{Descriptive Statistics}

Table 4.1 Summary of descriptive statistics

\begin{tabular}{lllll}
\hline & GDP & EXRT & INFL & ITRS \\
\hline Mean & 3.026325 & 100.7600 & 18.99780 & 17.59325 \\
Median & 3.698025 & 106.4650 & 12.71577 & 17.24500 \\
Maximum & 15.32916 & 358.8000 & 72.83550 & 31.65000 \\
Minimum & -13.12788 & 0.620000 & 5.388008 & 8.920000 \\
Std. Dev. & 5.453163 & 100.7271 & 16.86888 & 4.773328 \\
Jarque-Bera & 8.037391 & 5.265119 & 29.93777 & 1.510665 \\
Probability & 0.017976 & 0.071894 & 0.000000 & 0.469854 \\
Observations & 40 & 40 & 40 & 40 \\
\hline
\end{tabular}

Source: Author's computation using E-views software

The descriptive statistics for the variables showed that GDP growth and exchange rate averaged 3.03 per cent and 100.76 naira per dollar respectively whereas inflation and interest rates are associated with mean values of 18.99 and 17.59 per cent respectively. The standard deviations showed that all the variables are convergent to their respective mean values with the exception of GDP growth. In addition, the probability values of the Jarque-Bera statistics revealed that exchange rate and interest rate are normally distributed at 5 per cent level while GDP growth and inflation are not.

Unit Root Test

Table 4.2: ADF unit root test results

\begin{tabular}{llllll}
\hline Variable & \multicolumn{2}{l}{ Levels test results } & \multicolumn{2}{l}{ First difference test results } & $\begin{array}{l}\text { Order of } \\
\text { integration }\end{array}$ \\
\hline & $\begin{array}{l}\text { t- } \\
\text { statistic }\end{array}$ & Prob. value & t-statistic & Prob. value & \\
& -2.472 & 0.3394 & -10.450 & 0.0000 & $\mathrm{I}(1)$ \\
GDP & -0.444 & 0.9821 & -4.716 & 0.0028 & $\mathrm{I}(1)$ \\
EXRT & -4.069 & 0.0145 & $\mathrm{NC}$ & $\mathrm{NC}$ & $\mathrm{I}(0)$ \\
INFL & & & & & \\
& & & & & \\
ITRS & -2.229 & 0.4608 & -5.712 & 0.0002 & $\mathrm{I}(1)$ \\
\hline
\end{tabular}

Source: Author's computation using E-views software

@ECRTD-UK: https://www.eajournals.org/ Journal Level DOI: https://doi.org/10.37745/ijdes.13 
The unit root test results showed that only inflation is stationary at levels given that the probability value of its tests statistic is less than 0.05. This implies that the null hypothesis of unit root is rejected in this case. The other variables for the investigation were found to be non-stationary at levels. However, the first difference test showed that the variables become stationary at first difference. Thus, the results showed that inflation is integrated of order zero $[\mathrm{I}(0)]$ while GDP growth, exchange rate and interest rate are integrated of order one [I(1)]. The findings indicate that the variables are mixed integrated which makes it imperative for the application of bounds test for cointegration.

Bounds Cointegration Test

Table 4.3 Bound cointegration test results

\begin{tabular}{lll}
\hline \multicolumn{3}{l}{ Null Hypothesis: No long-run relationships exist } \\
\hline Test Statistic & Value & $\mathrm{k}$ \\
F-statistic & 10.199 & 3 \\
Critical Value Bounds & & \\
Significance & I0 Bound & I1 Bound \\
$\mathbf{1 0 \%}$ & 2.72 & 3.77 \\
$\mathbf{5 \%}$ & 3.23 & 4.35 \\
$\mathbf{2 . 5 \%}$ & 3.69 & 4.89 \\
$\mathbf{1 \%}$ & 4.29 & 5.61 \\
\hline
\end{tabular}

Source: Author's computation using E-views software

The results of the bounds cointegration test showed that the computed F-statistic (10.199) is greater than the corresponding critical value (4.35) at 5 per cent level. This implies that the variables are cointegrated and as such the null hypothesis that no longrun relationships exist is rejected. This implies that GDP growth has a long run relationship with exchange rate, inflation and interest rate. This, therefore, provides the empirical basis for estimating the ARDL model.

\section{Model Estimation}

The estimated ARDL model is presented in Table 4.4.

@ECRTD-UK: https://www.eajournals.org/ Journal Level DOI: https://doi.org/10.37745/ijdes.13 
Table 4.4 ARDL estimates (Sample: 1981 2020)

\begin{tabular}{|c|c|c|c|c|}
\hline \multicolumn{5}{|c|}{ Dependent Variable: GDP } \\
\hline \multicolumn{5}{|c|}{ Cointegrating Form } \\
\hline Variable & Coefficient & Std. Error & $\mathrm{t}$-Statistic & Prob. \\
\hline D(EXRT) & -0.085492 & 0.030177 & -2.833000 & 0.0088 \\
\hline D(INFL) & -0.139430 & 0.047415 & -2.940640 & 0.0068 \\
\hline D(INFL(-1)) & 0.011353 & 0.062839 & 0.180674 & 0.8580 \\
\hline D(INFL(-2)) & 0.099263 & 0.049629 & 2.000113 & 0.0560 \\
\hline D(ITRS) & 0.406412 & 0.214706 & 1.892881 & 0.0696 \\
\hline D(ITRS(-1)) & -0.401387 & 0.219105 & -1.831943 & 0.0784 \\
\hline CointEq(-1) & -0.876949 & 0.141938 & -6.178402 & 0.0000 \\
\hline \multicolumn{5}{|c|}{ Long Run Coefficients } \\
\hline Variable & Coefficient & Std. Error & t-Statistic & Prob. \\
\hline EXRT & -0.011307 & 0.009279 & -1.218573 & 0.2339 \\
\hline INFL & -0.270915 & 0.074588 & -3.632153 & 0.0012 \\
\hline ITRS & 0.464246 & 0.178721 & 2.597599 & 0.0153 \\
\hline $\mathbf{C}$ & 3.034406 & 3.139950 & 0.966387 & 0.3428 \\
\hline R-squared & 0.55776 & & $\operatorname{Prob}($ F-statistic) & 0.0072 \\
\hline \multicolumn{5}{|c|}{ Post-estimation diagnostics test results } \\
\hline \multicolumn{2}{|c|}{ Test type } & \multicolumn{2}{|c|}{ Test statistic } & Prob. value \\
\hline \multicolumn{2}{|c|}{ Breusch-Godfrey serial correlation test } & \multicolumn{2}{|c|}{ Chi-Square statistic } & 0.2123 \\
\hline \multicolumn{2}{|c|}{ White's heteroskedasticity test } & \multicolumn{2}{|c|}{ Chi-Square statistic } & 0.2401 \\
\hline \multicolumn{2}{|c|}{ Ramsey RESET test } & \multicolumn{2}{|c|}{$\begin{array}{l}\text { Cn1-square statistic } \\
\text { F-statistic }\end{array}$} & 0.0587 \\
\hline
\end{tabular}

The results showed that exchange has a significant negative effect on GDP growth in the short run. This implies that increase in exchange rate or depreciation of the naira adversely affects economic growth in Nigeria given the large dependent of the economy on importation. At the same, inflation rate impacted negatively on economic growth in both long and short run. This finding is consistent with the a priori expectations and suggests that rise in the price level undermines the growth of the Nigerian economy. In addition, interest has a significant positive effect on GDP growth. Although this finding is contrary to the theoretical expectations, it explains the reality in Nigeria, where businesses and households tend to borrow even as interest rate increases, but tend to cut corners by reducing the quality of their products and services or pass-on the increased costs of borrowing to consumers by increasing prices. The R-squared $(0.557)$ showed that 55.7 per cent of the variations in GDP growth are explained by the explanatory variables. Additionally, the probability value of the F-statistic indicates that the variables are collectively significant in explaining changes in GDP growth. Furthermore, the error correction coefficient $(-0.877)$ revealed at the model can adjusts to long run equilibrium position at a speed of 87.7 per cent. The post-estimation tests showed that the model is free from serial correlation and heteroscedasticity given that the associated probability values of the test statistics are greater than 0.05 . The stability

@ECRTD-UK: https://www.eajournals.org/ Journal Level DOI: https://doi.org/10.37745/ijdes.13 
test result also indicates that the coefficients are stable over the study period. Thus, the entire model can be relied upon for policy formulation and forecast.

\section{CONCLUSION AND RECOMMENDATIONS}

This study centered on the empirical investigation of the relationship between exchange rate and economic growth (measured by annual GDP growth) in Nigeria. In addition to exchange rate, the effects of inflation and interest rate on GDP growth was equally investigated. Time series data on the variables were obtained from the CBN Statistical Bulletin and WDI. The data analysis techniques include descriptive statistics, unit root and bounds cointegration tests and ARDL model. The findings are summarized as follows:

-There is evidence of mixed integration in the variables from the unit root test results. While inflation is stationary at levels, the other variables in the model were stationary at first difference.

-The bounds cointegration test showed that long run relationship exists between GDP growth and the underlying explanatory variables.

-Exchange rate has a significant negative relationship with GDP growth in the short run, which implies that increase in exchange rate is detrimental to the growth of the Nigerian economy.

-Similarly, inflation rate has a significant negatively effect on GDP in both long and short run.

-There is evidence of a significant effect of interest rate on GDP in the long run.

The implication of exchange rate on macroeconomic performance has remained a source of concern to policymakers and researchers following the growing integration of the domestic economy to the rest of the world. Consequently, this study examined the effect of exchange rate on economic growth in Nigeria. In addition to exchange rate, the effects of inflation and interest rates on economic growth were equally investigated. The findings showed that exchange rate and inflation negatively impacted on economic growth. This finding indicates that increase in exchange rate and price level is detrimental to the growth of the Nigerian economy. There is evidence of a significant positive effect of interest rate on GDP growth. Based on the findings, this study concludes that increase in exchange rate undermines the growth of the Nigerian economy. It is equally concluded that inflationary pressures also dampen economic growth in Nigeria.

@ECRTD-UK: https://www.eajournals.org/ Journal Level DOI: https://doi.org/10.37745/ijdes.13 


\section{Recommendations}

1. The federal government through the CBN should ensure that exchange rate policy should is consistent to provide opportunity for a realistic and stable exchange rate capable of driving economic growth in Nigeria.

2. Policymakers should promote price stability by mitigating inflationary pressures through inflation targeting which has the potential to stimulate the growth of the Nigerian economy.

3. The monetary policy committee (MPC) should ensure that interest rate remain that a level capable of promoting investments to enhance economic growth in Nigeria.

\section{REFERENCES}

Adeniran, J. O., Yusuf, S. A. \& Adeyemi, A. O. (2014). The Impact of Exchange Rate Fluctuation on the Nigerian Economic Growth: An Empirical Investigation.International Journal of Academic Research in Business and Social Sciences, 4(8), 224-233.

Aghion, P., Bacchetta, P., Ranciere, R. \& Rogoff, K. (2009). Exchange rate volatilityand productivity growth: the role of financial development. Journal of Monetary Economics, 56 (4), pp. 494-513.

Ajakaiye, D. O. (2001). Impact of Exchange Rate Depreciation on Sectorial Prices, NISER Monograph Series, (1986-2000).

Akinlo A. E. (2003). exchange rate depreciation and currency substitution in Nigeria, African Review of Money Finance and Banking 139-143.

Akpomi, M.E \& Kayii, N.E (2021). Relationship between grants disbursement and the delivery of business studies in public Junior Secondary Schools in Rivers State. International Journal of Advanced Multidisciplinary Research and Studies, 2(1), 7-14.

Alasha, R. U. (2020). The impact of exchange rate fluctuations on economic growth in Nigeria. Department of Economics, Faculty of management and Social Science,Baze University, Abuja. Project Paper.

Aliyu, S. R. U. (2011). Impact of oil price shock and exchange rate volatility on economic growth in Nigeria: An empirical investigation. MPRA Paper 16319, University Library of Munich, Germany, rev. 10 Jun 2009.

Benson, U. O. and Victor, E. O. (2012). Real exchange rate and macroeconomic performance: Testing for the balassa-samuelson hypothesis in Nigeria. International Journal of Economics and Finance, 4(2): 127-34.

Dickey, D. A., \& Fuller, W. A. (1981). Likelihood ratio statistics for autoregressive time series with a unit root. Econometrica: Journal of the Econometric Society, 1057-1072.

@ECRTD-UK: https://www.eajournals.org/

Journal Level DOI: https://doi.org/10.37745/ijdes.13 
Edward, S. \& Levy, Y. E. (2003). Flexible exchange rate as shock absorber. NBER Working paper, 9867.

Gbosi, A. N. (2005) Money, Monetary Policy and the Economy. Port Harcourt: Sodek.

Hicks, J. R. (1937). Mr. Keynes and the classics: 'A suggested interpretation' Econometrica, 5(2): 147-59.

Jongbo, O. C. (2014). The impact of real exchange rate fluctuation on industrial output in Nigeria. Journal of Policy and Development Studies, 9(1): 268-78.

Jhingan, M. L. (1997). Macroeconomic Theory, Vrinda Publications Ltd, Delhi, pg. 697.

Jhingan M. L. (2005). International Economics, 5th Edition, Vrinda Publications (P) Limited Delhi.

Johansen, S. \& Juselius, K. (1990). Maximum likelihood estimation and inference on cointegration with application to the demand for money. Oxford Bulletin of Economics and Statistics, 52, pp. $169-210$.

Maddison, A. (1982). Growth and Slowdown in Advanced Capitalist Economies:Techniques of Quantitative Assessment. Journal of Economic Literature Vol. 25, No. 2 Jun., 1987), 649-698.

Mordi, C. N. (2006). Challenges of exchange rate volatility in economic management in Nigeria. IBullion, 30(3). July - Sept.

Obansa, S. A., Okoroafor, O. K., Aluko, O. O., \& Eze, M. (2013). Perceived relationship between exchange rate, interest rate and economic growth in Nigeria (1970-2010). American Journal of Humanities and Social Sciences. 1(3), 116-124.

Odusola, A. F. \& Akinlo, A. E. (2001). Output, inflation, and exchange rate in developing countries: An application to Nigeria. The Development Economies, 30(2): 199-222.

Olisadebe, E.U. (1991). Appraisal of recent exchange rate policy measures in Nigeria. CBN Economic and Financial Review, 29(2), 452-465.

Osuka, B. O., \& Osuji, F. I. (2008) Foreign exchange fluctuations and Nigeria's fledging economy. The Nigerian Banker, July - September, 38-46.

Pesaran, M. H. \& Shin, Y. (1999). An autoregressive distributed lag modelling approach to cointegration analysis. Chapter 11 in S. Strom (ed.), Econometrics and Economic Theory in the 20th Century: The Ragnar Frisch Centennial Symposium. Cambridge University Press, Cambridge.

Pesaran, M. H., Shin, Y., \& Smith, R. J. (2001). Bounds testing approaches to the analysis of level relationships. Journal of Applied Econometrics, 16, 289-326.

@ECRTD-UK: https://www.eajournals.org/

Journal Level DOI: https://doi.org/10.37745/ijdes.13 
International Journal of Development and Economic Sustainability

Vol.10, No.1, pp.41-55, 2022

ISSN: 2053-2199 (Print), ISSN: 2053-2202(Online)

Siyan, P. \& Adewale, E. A. (2000) An assessment of nexus between infrastructural development and Nigerian economic growth. African Journal of Business Management. 11(18):470-477.

Solow, R. M. (1994). Perspective on growth theory. The Journal of EconomicPerspective 8(1) 45-54.

Todaro, M. P., \& Smith, S. C. (2004). Economic Development (8th Ed.). Delhi: Pearson Educational (Singapore) PTE Ltd.

Wehnam, P. D. \& Nelson, J. (2013). Causes of Interest Rate Volatility and its Economic Implications in Nigeria. International Journal of Academic Research in Accounting, Finance and Management Sciences Vol. 3 (4) 27-32.

@ECRTD-UK: https://www.eajournals.org/

Journal Level DOI: https://doi.org/10.37745/ijdes.13 